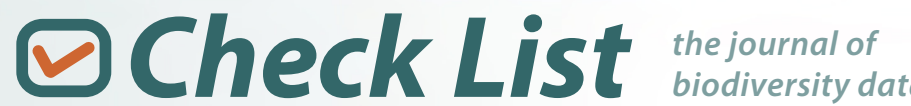

๑

\section{First record for Malawi of Kenrick's Starling (Poeoptera kenricki Shelley, 1894) (Aves: Sturnidae)}

\author{
Joshua I. Engel ${ }^{1 *}$, David Willard ${ }^{1}$, Potiphar M. Kaliba ${ }^{2}$ Lovemore Mazibuko $^{2}$ and John M. Bates ${ }^{1}$ \\ 1 Field Museum of Natural History, Science and Education, 1400 South Lake Shore Drive, Chicago, IL, USA 60605 \\ 2 Museums of Malawi, P.O. Box 30360, Chichiri, Blantyre 3, Malawi \\ * Corresponding author. E-mail: jengel2@fieldmuseum.org
}

\begin{abstract}
We report on the first record of Kenrick's Starling for Malawi. A flock of more than 150 birds was observed in the Misuku Hills in far northern Malawi; two individuals were collected for voucher specimens and deposited in museum collections.
\end{abstract}

Key words: new record; endemic bird; East Africa

On 17 June 2007, while participating in a joint Museums of Malawi (MoM) and Field Museum of Natural History (FMNH) expedition to the Misuku Hills of northern Malawi, D. Willard, P. Kaliba and L. Mazibuko encountered a flock of more than 150 small black starlings. L. Mazibuko was able to procure two specimens, which were later identified as Kenrick's Starlings (Poeoptera kenricki Shelley, 1894), a species previously unrecorded in the country. This is the first published addition to Malawi's bird list since Golden Pipit [Tmetothylacus tenellus (Cabanis, 1878)] in 1999 (Dowsett-Lemaire and Dowsett 2006).

Kenrick's Starling is a generally common East African endemic, found in montane forest and forest edge habitats of Mount Kenya and the Eastern Arc Mountains of Tanzania (Figure 3; Fry 2000). The Malawi birds were found in an unidentified fruiting tree in an isolated copse of trees well away from any forest at an elevation of $1,400 \mathrm{~m}\left(09.67^{\circ} \mathrm{S}, 033.52^{\circ} \mathrm{E}\right)$. The species has since been found (in 2008) as close to the Misuku Hills as Maguli Forest Reserve, Tanzania, ca. $75 \mathrm{~km}$ northeast of the Malawi location (Zoological Museum of Copenhagen (ZMUC) specimens). Prior to the collection of the ZMUC specimens, the closest known records to the Misuku Hills locality were from Tandala Mission and Mdando Forest, Tanzania, ca. $85 \mathrm{~km}$ to the northeast and ca. $140 \mathrm{~km}$ to the east, respectively
(Britton 1980; Fuggles-Couchman 1984; Fry 2000).

Identification of the specimens (FMNH 452984 and MoM 2007.1.64) - both are males - is straightforward. The only entirely dark starlings in Africa are males of the three members of the genus Poeoptera: Stuhlmann's Starling [P. stuhlmanni (Reichenow, 1893)], Narrow-tailed Starling (P. lugubris Bonaparte, 1854), and Kenrick's Starling. The specimens' relatively short tail eliminates Narrow-tailed Starling and the matte black plumage, lacking a glossy blue sheen, rules out both Narrow-tailed and Stuhlmann's Starlings (Figures 1 and 2).

The occurrence of Kenrick's Starling in Malawi is not particularly surprising, given how close to the border it occurs in Tanzania. However, given that previous work in the Misuku Hills failed to find this rather conspicuous species (summarized in Dowsett 1973), this could represent a case of recent range expansion. On the other hand, Kenrick's Starling is known to undertake altitudinal migration and is reported to be nomadic (Feare and Craig 1999; Fry 2000), and could be an occasional wanderer to the region. Three additional forest species reach the southern limit of their ranges in this area: Shelley's Greenbul (Andropadus masukuensis Shelley, 1897), Spot-throat [Modulatrix stictigula (Reichenow, 1906)] and Dark Batis (Batis crypta Fjelsdå, Bowie, \& Kiure, 2006) (Dowsett-Lemaire and Dowsett 2006).

\section{ACKNOWLEDGEMENTS}

The specimens were collected under permit NRCM/77/O25 from the National Research Council of Malawi. We thank Christopher Salema for providing photographs of the specimen at MoM, Niels Krabbe for confirming information about the ZMUC specimens, and to Tim Davenport of the Wildlife Conservation Society for information about Tanzanian reserves. 


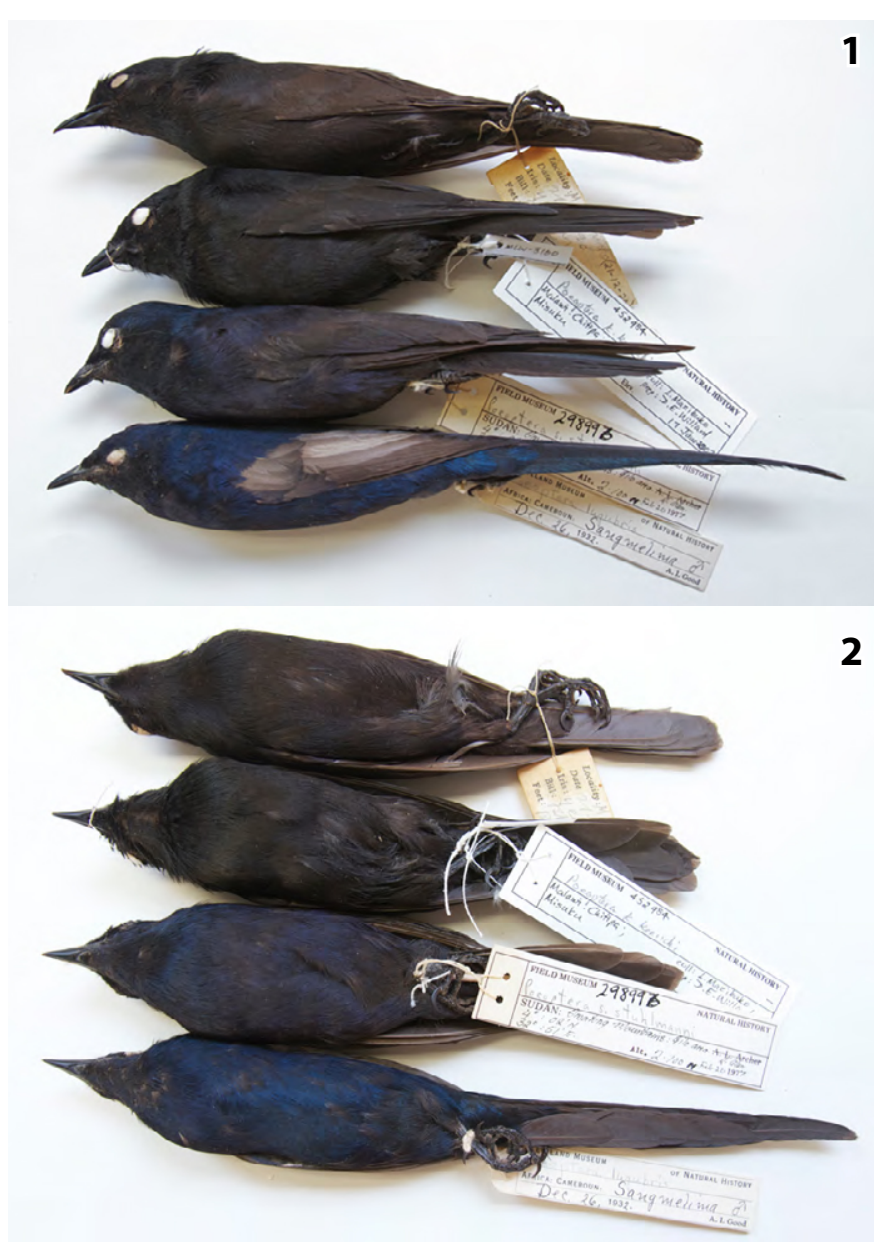

Figures 1 and 2. Malawi specimen of Kenrick's Starling (FMNH 452984; second from top), with other Poeoptera starlings: Kenrick's Starling (FMNH 198918; top), Stuhlmann's Starling P. stuhlmanni (FMNH 298996; second from bottom) and Narrow-tailed Starling P. lugubris (FMNH 273630; bottom). Note the color difference between Kenrick's Starling and the other two Poeoptera species.

\section{LITERATURE CITED}

BirdLife International and NatureServe. 2012. Bird species distribution maps of the world. Accessed at http://www.birdlife. org/datazone/info/spcdownload, 8

August 2013.

Britton, P.L. (ed.). 1980. The birds of East Africa. Nairobi: East Africa Natural History Society. 271 pp.

Dowsett, R. J. 1973. The forest avifauna of the Misuku Hills in Malawi. Zambian Museums Journal 4: 19-36.

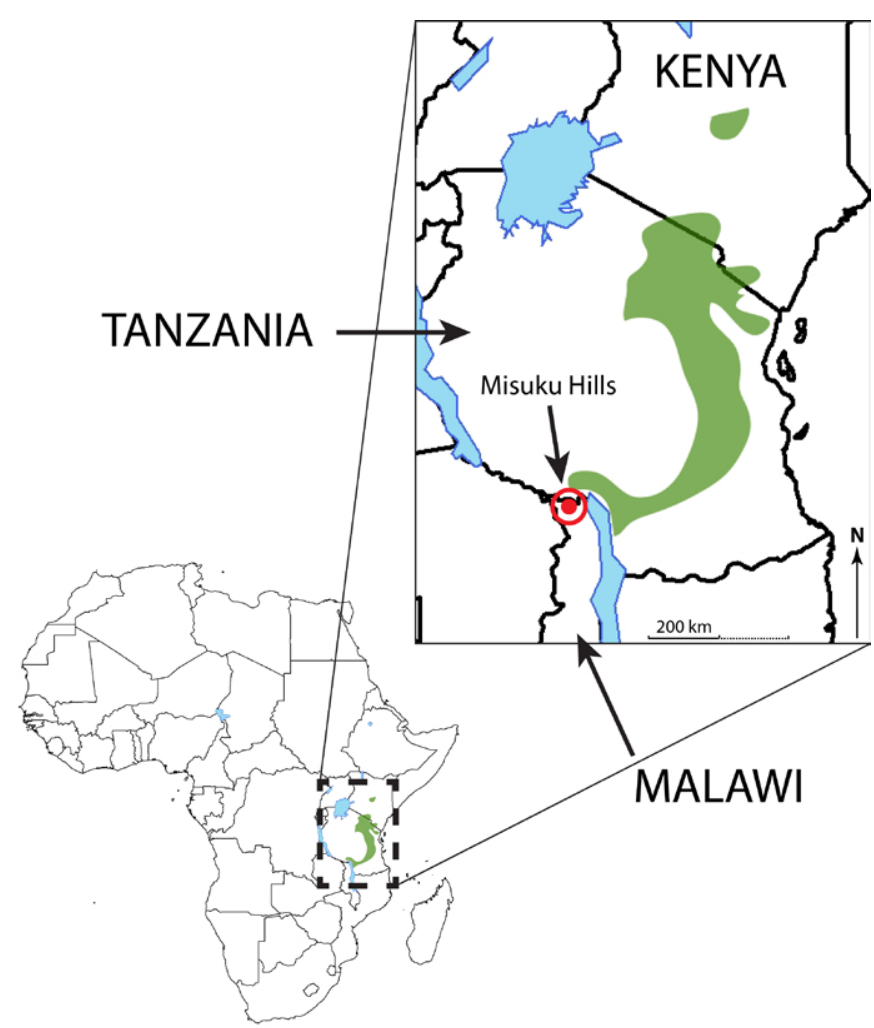

Figure 3. Approximate global range map of Kenrick's Starling, based on data from Birdlife International and NatureServe (2012). The Misuku Hills site is marked by a red circle.

Dowsett-Lemaire, F. and R. Dowsett. 2006. The birds of Malawi. Liège: Tauraco Press. 556 pp.

Feare, C. and A. Craig. 1999. Starlings and mynas. Princeton: Princeton University Press. 288 pp.

Fry, C.H. 200o. Poeoptera kenricki; pp. 576-577, in: C.H. Fry, S. Keith and E.K. Urban. (eds.). The Birds of Africa Vol. VI. London: Academic Press.

Fuggles-Couchman, N.R. 1984. Notes on the distribution of some Tanzanian birds, part 2. Scopus 8(4): 81-92.

Author contributions: JIE and JMB wrote the text, DW, PMK, and LM organized and conducted the field work, DW identified the specimens.

Received: 14 April 2014

Accepted: 20 June 2014

Academic editor: Thiago V. V. Costa 